\title{
Characteristics of a central change programme within a governmental bureaucracy: a grounded theory study
}

\author{
Ronald de Korte, RA RE RO CIA • \\ Gert van der Pijl, RE
}

Published online: 1 October 2008

(C) The Author(s) 2008. This article is published with open access at Springerlink.com

\begin{abstract}
Purpose The purpose of the paper is to present a theory of organisational change within the setting of a governmental bureaucracy. Design/methodology/ approach Orthodox grounded theory is employed in the setting of a change programme in 12 Audit departments of the Dutch Ministries (public-sector). Findings The examined organisational change has specific characteristics. The Dutch 'ministerial autonomy' and the clearly recognizable role types of the key figures involved have a strong impact on the change programme and the realisation of its goals. Research limitations/implications Findings are derived on the basis of a substantive case study of the change programme of the Dutch Departmental Audit function. The research sheds new light on characteristics related to the occupational group of Chartered Accountants and characteristics of a governmental bureaucracy and it helps to understand change programmes within this bureaucracy. Practical implications The grounded theoretical model draws attention to the impact of key figures and circumstances on a change programme within the central government. Originality/value The paper builds on theories of organisational change but applies them in the typical context of the Dutch civil service where ministerial autonomy, on the one hand, and a move in the direction of more centrally organised activities (concern idea), on the other, require a difficult balancing act of all players in the change arena.
\end{abstract}

Keywords Organisational change $\cdot$ Public sector organisations . The Netherlands

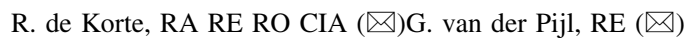

Erasmus School of Accounting and Assurance (ESAA), Erasmus School of Economics,

Erasmus University of Rotterdam, Rotterdam, The Netherlands

e-mail: r.de.korte@acs.nl

G. van der Pijl, RE

e-mail: vdpijl@home.nl 


\section{Abbreviations}

ABD Senior Public Service (Dutch: 'Algemene Bestuursdienst')

AD Audit Department

BZK The ministry of the Interior and Kingdom Relations

CAD A staff division of the Ministry of Finance. 'Coordination Audit Policy Ministries'

DAD Ministerial Audit Department

DG Director General (Internal oriented top manager of a Ministry)

FEZ Financial and Economic Affairs (A ministerial staff division)

FIN Ministry of Finance

IBO Interdepartmental Policy Investigation

IODAD Interdepartmental Meeting of Directors of the Audit Departments

IOFEZ Interdepartmental Meeting of the divisions Financial and Economic Affairs

NIvRA The Royal Dutch Institute of Registered Accountants. The professional group of chartered accountants (Royal NIvRA)

RA 'Registered Accountant'; the Dutch Chartered Accountant. A RA passed the exam of a specific post-academic education program that makes no distinction in public, governmental or internal financial auditing

SG Secretary General (External \& Internal oriented top manager of a Ministry)

VBTB An interdepartmental change project named: 'VBTB'. An abbreviation of 'From Policy Budgets to Policy Accountability'

ZIN Dutch for 'sense', 'meaning' or 'usefulness'. Here it is used as a companyname and the name of a sense-making course for $\mathrm{AD}$-management, organised by ZIN

\section{Introduction}

This paper presents insights on organisational change within the setting of a governmental bureaucracy. It starts with the outcome of a Grounded Theory research on the transition of the Dutch ministerial audit department (the case). Next it elaborates on theories and describes events within the civil service that are relevant to understanding the characteristics of the transition of the audit departments (ADs). It describes some typical Dutch discussions and situations together with general behavioural aspects of organisational change. Grounded theory is used because the study is still in a descriptive stage where we try to get grips on decision making problems in this context. Therefore this study does not aim at testing hypotheses but at understanding the problem area and theory development.

\section{The case}

Within the central government the call for outsourcing the financial audit departments became very loud in the year 1999. A survey on the negative image 
of the financial audit departments within the ministries became the starting impetus for the interdepartmental policy study (IBO) on the Audit Departments. The 'Kordes committee', which carried out the study, saw the value of the ADs' experiences for the audit of the new approach to government budgeting and the accountability process within the Dutch central government (Kordes 2001). This new approach requires ministries to state not just monetary amounts and objects of expenditure in their budgets, but also their policy objectives, how they intend to achieve them and the estimated cost (ARK 2004).

The Kordes Committee advised to give the ADs a new assignment, directed by a ministerial audit committee. Audits need to cover more than only certification of the annual reports and compliance audits. These 'operational audits' can have a wide range of objectives. To realise this change the accountancy departments have to train their employees and attract new employees with backgrounds in other areas besides financial auditing. They also need to convince their clients that they can add more value since they are more widely oriented audit department (Kordes 2001).

The report of the Kordes Committee was discussed with the stakeholders and was the basis of a second report, namely, The Quality Plan for the Audit Function of the Central Government. It was drafted by the Ministry of Interior and Kingdom Relations. The Cabinet sanctioned 'the Quality Plan' in February 2002.

Some AD directors started the transition of their AD before 'the Quality Plan' was formally accepted. The Interdepartmental Meeting of the Directors of the Audit Departments (IODAD) discussed the outcome of the report and the consequences of its implementation for their role as the governmental accountants, for the structure and staffing of their $\mathrm{AD}$, and for the organisation of the central support. They appointed a project manager. A steering committee was formed by stakeholders from several ministries. The chairman of IODAD was a member of this steering committee.

Neither steering committee nor project management had any formal power to make the AD directors change their AD's. The Dutch 'ministerial autonomy' demands the project management to convince, motivate and share information, in order to get all the AD directors moving towards 'the Quality Plan'.

The situation is somewhat peculiar because of the fact that the IODAD-members were, in practice, responsible for the implementation of 'the Quality Plan' within their audit department, but they still need the permission of their superiors for the implementation. They discussed with their colleagues the consequences of the change and their related personal feelings. They partly needed to change themselves.

The project managements' actions during the transition were taken in cooperation with IODAD and supported by a department of the Ministry of Finance, namely, 'Coordination Audit Policy Ministries' (CAD). These actions include: research, organising meetings, financing pilots, facilitating benchmarks and publishing a periodical (Pennekamp and Vlasveld 2005).

In his last report (Pennekamp and Vlasveld 2004), the project manager assessed the outcome of the project at the end of 2004 in the following way:

- All the former financial audit departments are just about to be transformed into audit departments with a wider objective and a broader scope. Almost all the 
Audit Committees broadened the scope of the audit function as described in 'the Quality Plan'. Nevertheless, the transition of many audit departments is unfinished.

- Cutbacks on personnel are one of the reasons why management of the ADs gave little priority to operational audits. The financial audits consume most of the available human capacity.

- The ADs mainly invested in their organisational structure and in their audit products. The education of their staffs merely focused on the technical aspects of auditing. In the initial phase, little attention was paid to behavioural change of employees and adjustments in the departmental culture. Therefore, the project management organised a specific programme for the management team and for the most senior staff of the AD (the director excluded). The program focussed on changing the structure of the audit departments and the scope of the audits. This was accompanied by professional training for the auditors. There was little attention to changing the culture and the attitude of individual auditors.

- The idea of a pool of audit specialists, as mentioned in 'the Quality Plan', is transformed to a virtual pool of employees that can be assigned to audits across departments.

\section{Methodology}

Qualitative researchers see their aim as one of understanding how people make sense of their lives and how people come to understand and manage day-to-day situations (Miles and Huberman 1994). For the purpose of this research, the authors have chosen to adopt an in-depth ethnographic-type investigation (using interviews, observation and document analysis) within the context of the audit function, which is organised as a separate department within each Ministry.

The research should give us some understanding of future transitions in similar circumstances. We use Grounded Theory (Glaser 1978, 1992) as a research methodology because it allows theories to be extended and is based on unbiased observations of reality. A grounded theory researcher wants to understand what is happening in the research situation and how the key figures manage their roles. It is mostly done through observation, conversation and interview. Collected data is documented and labelled. Constant comparison is the heart of the GT-process. It starts with comparing the data with other data. Emerging theory is compared with new data. The results of this comparison are coded. The researcher identifies categories (themes or variables) and their properties (sub-categories). In the coding phase, certain theoretical propositions will be formulated. By constant comparison, some propositions will remain as core categories. In the memo-ing phase the researcher writes notes to himself about the (core) categories, properties and their relations in order to gradually form his own specific theoretical framework. This process iterates until no new theory emerges. Then he adds the findings to the sample through theoretical sampling. Here one can add existing theories, but just as 'data'. It increases the diversity, searching for different properties. The sorting 
occurs when all categories are saturated. Writing starts after sorting and should be 'just elaborating' on the items the researcher sorted (Dick 2002).

The purpose of the research presented in this article is not to provide a comprehensive description, but rather to generate a theory of change within a particular substantive setting. More precisely, we want to understand how change works in a bureaucratic governmental context, such as the one in the Netherlands. This purpose has resulted in the selection of orthodox, or Glaserian, grounded theory as the methodology of choice (Glaser and Strauss 1967; Glaser 1978, 2001). Orthodox grounded theory is well suited to the study of complex entities because of its ability to produce a multifaceted account of organisational action in context (Locke 2001). It generates an inductive theory about a substantive area that accounts for a pattern of behaviour which is relevant and problematic for those involved' (Glaser 1978). The central issue in a grounded theory study is to know what the informants' problem (or main concern) is and how they seek to resolve it (Glaser 1992).

We do not make extensive use of citations from our interviews. We also do not intent to emphasise the 'voice' of the participants. Orthodox grounded theory is not concerned with accurate description of personal ideas. There is no requirement to provide data that acts as 'evidence' or 'proof of the theory' (Glaser 2003). Following Glaser (2003), we use our data not to 'prove' our theory but merely to 'illustrate' so that the reader can comprehend and make sense of the grounded theory and understand the 'conceptual grab'.

\section{Research design}

Our investigation addresses the transition with an emphasis on central project management. It aims at understanding the logic of the flow of events, as it has been observed by us for 3 years. This transition is just one of many within the central government. To some extent, however, it is characterised by the dominant occupational group, namely, the (governmental) chartered accountants. We looked at some characteristics of the transition regarding the roles of the key persons. We focused on the relation between the effects of their roles and the dominant culture of the ADs and its surroundings. The research should give us some understanding of future transitions in similar circumstances.

Orthodox grounded theory comprises three types of coding (open, selective and theoretical), constant comparison of data, theoretical sampling, core category generation, saturation of categories, memoing, sorting, and writing-up (Glaser 1998). In orthodox grounded theory 'all is data' (Glaser 2001). We used interviews, observation, document analysis and we combined theories that fit well. For 3 years (2002-2004) we observed the events through (43 semi-structured and often recorded) interviews, (several non-structured) informal conversational-type interviews that were field-noted but not recorded, document investigation (over 50 articles and reports, 30 min of committee meetings), attending (4) seminars, et cetera. Most of these interviews were conducted with people that have a real impact on the transition of one or more ADs. We interviewed members of the committee 
that published the transition plan, as well as the project management and some Audit directors that implemented it. Some interviewees were invited to contribute to the transition as a coach or trainer, while others 'went through' the transition as an auditor.

The initial interviews were meant to scope the research and to define the objective in more detail. We generated some thoughts about the issue of change within the central government and, more specific, within the setting with chartered (governmental) accountants in charge. In the first interviews, we were merely looking for a description of the project and its history. We were also seeking some insight into:

- the relation between central project management and the individual audit departments;

- the 'concern thought' based on the Cabinets' policies aimed at centralisation;

- inter-ministerial deliberations;

- ministerial autonomy;

- the power balance between and within the separate Ministries and their auditing departments.

These first preliminary interviews were non-structured and informative on the interviewees' personal thoughts about the transition.

- 'How does the transition of your AD effect your daily work?' and

- 'What is the influence of the central programme management on this transition?'

The analysis of the answers from the preliminary interviews gave us enough reason to plan more interviews, to decide on what types of data to seek, and what kinds of questions to ask. We decided to follow two related tracks:

- Interviewing the members of the transition project combined with an analysis of the project's archive which went back to the 'Kordes committee' and with the minutes of the monthly meeting of AD-directors.

- Interviewing the AD-director, a MT-member and an auditor of five ADs combined with occasional non-structured talks with auditors, directors and MTmembers from most of the ADs.

The main goal was to understand why the transition process developed 'as it did' during 2002 up till and including 2004.

We choose not to visit all 12 ADs, but focussed on the five that seemed to be most proactive and in line with the transition plan. The majority of these five call themselves 'ahead' and 'independent of the project management'. In interviews with auditors of these ADs we noticed gaps between the ideas, plans and intentions and the daily practice. Informal contacts with auditors of most of the other ADs never the less showed that the not-selected ADs had not overtaken the selected ADs in the implementation of the transition plan.

Most non-structured interviews and non-planned contacts took place at the university, during seminars, et cetera. The semi-structured interviews were conducted in the participants' workplace of the five chosen ADs and had as a topic list: 
- The most essential assignments of the AD: in recent years and 'tomorrow'.

- The effects of the AD-transition on their products, personnel policy, relation with customers and principals.

\section{Findings related to the transition from 2001 until 2004}

Our grounded Theory analysis shows the dominance of three overall labels: Power, Motivation and Communication. They often re-enforce each other but they also sometimes overlapped. The overall labels helped us to code events and to combine detailed codes in more abstract labels at a higher level. These labels can easily be grouped by sub-environment, as shown in Fig. 1. The sub-environments, or 'label groups', are the recognisable acting entities within the transition. Based on the dominant labels within the label groups, we describe the following label groups:

- Circumstances: These are the characteristics of the civil service (bureaucracy, culture and image, ministerial autonomy versus centralisation) and the prevailing dominant forces (demands from the Parliament and the Dutch Court of Audit, cutbacks by the cabinet).

- Concern: The interdepartmental relations (SG-consultation, IODAD) with its centralisation drive of two kernel ministries and the autonomy drives of the individual ministries. Dominant labels are: Politics, Unclearness and Mistrust.

- Change Agents, and

- The individually Changing ADs.

Two groups act as Change Agents: the Interdepartmental Meeting of Directors of the Audit Departments (IODAD) and the Project Management. In 2001, the Project took over the management of the transition stimulating actions and kept IODAD informed and involved.

Fig. 1 Four label groups

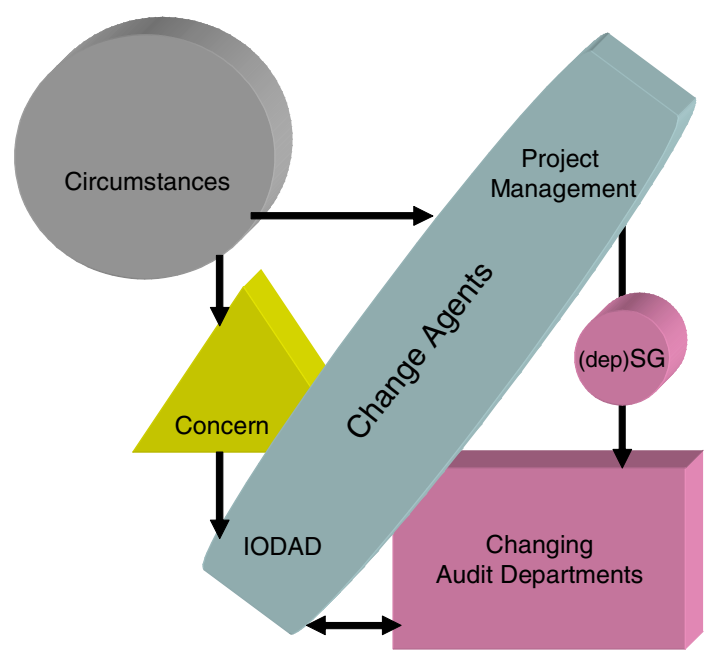


Circumstances and the pressure to centralise, normalise and standardise over the departments (called the 'Concern thought') act on the Change Agents. They were positioned amidst this Concern pressure and the Autonomy drives of the individual ADs. This drive for autonomy is primarily based on Ministerial autonomy, which is often described as a typical Dutch phenomenon (Postma 1996; Hondeghem and Vandenabeele 2005). Ministerial autonomy means that departments are only responsible to their own minister and not to the prime minister or the cabinet as a whole. The civil servants focus on the social interest via their Minister and Secretary General (SG). The (deputy) SG plays an important role within the duality of the Concern thought, based on a Cabinets vision, and the Ministerial autonomy. Concern politics cannot be apposed; it needs consensus like many decisions made in The Netherlands with its famous Polder model. ${ }^{1}$

A second basis of the individual ADs autonomy drives is a mixture of:

- the Audit directors' professionalism, based on regulations of and their loyalty to the professional group of Chartered Accountants (Royal NIvRA), and

- their will to serve their Secretary General and the special interests of their Minister and Ministry.

In Fig. 1, we drew the Change Agents overlapping the Concern and the Changing ADs: IODAD consisted of the directors of the individually Changing ADs and was supported by the CAD, namely, 'Coordination Audit Policy Ministries'. The CAD was a unit of the Ministry of Finance (and thus part of the 'concern'). Its goal was to support the ADs by describing standard approaches, tools and memorandums and by organising seminars et cetera. The CAD-director was chairman of IODAD and the CAD was often seen as the 'controller' of the 'concern'. We see IODAD as the link between the ministerial ADs and the 'concern'. The Project Management focussed on the individual ADs, but the influence of the kernel ministries was clear. The project was financed by the Ministry of the Interior and Kingdom Relations, situated within the Ministry of Finance and supported by CAD.

The arrows show the direct effect of the circumstances on the project, on the 'Concern' and, via the 'Concern' on IODAD. IODAD is influenced by the ADdirectors, the Project management and the (deputy) SG. The Project management directly influenced the (deputy) SGs and AD-directors. The Change Agents influenced the ADs mostly via their AD-director.

The picture misses an arrow representing the effect of Circumstances on the ADs. In this article we focus on the effects of the Circumstances and the Concern on the transition of the ADs via the Change Agents.

In Fig. 2 we separate the Change Agents in IODAD and the Project Management. During the second half of the period the Project Management was active, it informed IODAD about its initiatives and the outcome of its research and actions. IODAD however had its mind more on a possible new 'attack' on the ADs. A new Interdepartmental Policy Investigation (IBO) called 'The administrative pressure of

\footnotetext{
1 The word 'poldermodel' and especially the verb 'polderen' (English: to polder) has been used pejoratively by some politicians to describe the 'slow' decision making process which characterises Dutch politics where all parties have a say and must be heard. Advocates of the 'poldermodel' call attention to thoroughness and motivational advantages.
} 
Fig. 2 Five label groups; Change Agents split in IODAD and Project

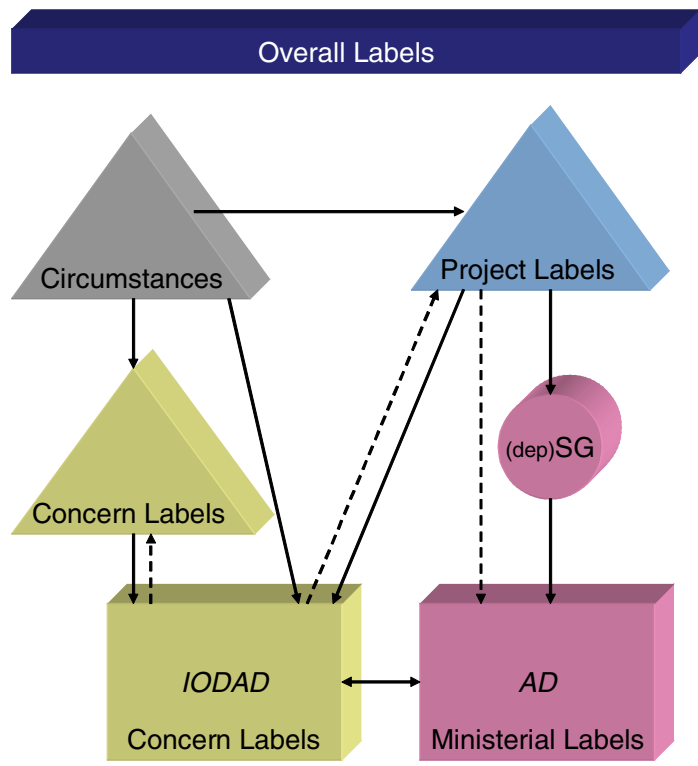

Rules and the Control Tower' combined with new cutbacks and high expectations on the legitimacy of expenditures. These are all signals that can be interpreted as a reason 'to get back to the financial audit' and possibly as the end of the 'Quality Plan'.

The project manager mentioned cutbacks as an important reason for the status quo at the end of 2004. The arrows show the direct effect of the circumstances on the project, on the Concern and via the concern on IODAD. The amount of effect is projected in an arrow and respectively a dotted arrow.

Figure 3 shows a more detailed view of Fig. 2. It presents the five label groups, each with their most important labels. The overall labels Power and Motivation characterise the transition as an imposed change. As we will show, an imposed change easily leads to the basic communication characteristics, namely, top-down and informing.

The ideas of becoming a learning organisation, attracting new talented youngsters and motivating chartered accountants to broaden their scope are difficult to realise in every organisation. It is even more difficult within the civil service that wrestles with a dusty and stiff image. It became almost impossible when the Cabinet decided for further cutbacks within a year, after it confirmed the 'Quality Plan'.

Motivation and Communication, and also the circumstance of 'lack of formal Power' within the project, effect the project labels and directly influence the 'steering' of the transition of the individual ADs (Ministerial labels). Within the bureaucracy, the communication is hierarchical, top down and formal. The influence of the project, including IODAD, on the concern labels has a continued effect on the relations within an AD. Unclearness and Hierarchical behaviour motivate to Caution and Conservatism. It all points to Conservatism! Within the surroundings of 


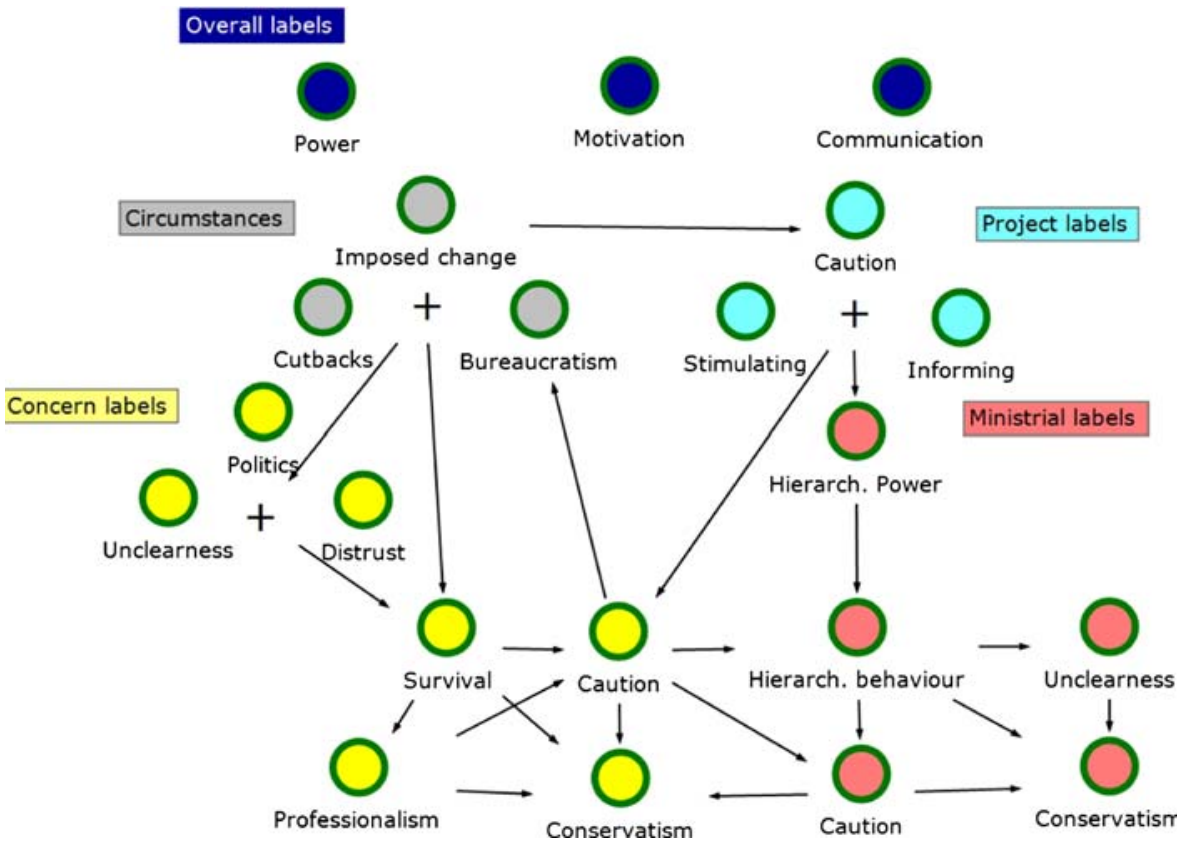

Fig. 3 Detailed labels related to the label groups

Bureaucratism $^{2}$ and Cutbacks, the Imposed change generates an important conservative Power that appeals to a Survival drive. Unclearness, Politics and (two-way) Mistrust enforce the Survival oriented actions. They surely minimise the number and strength of the attempts to change.

Survival leads to Professionalism, Conservatism and Caution. Moreover, these labels enforce each other. Cautious behaviour of AD directors (IODAD) leads via Bureaucratism to enhanced Power. Delayed improvement of the negative image of a bureaucracy, called 'Bureaucratism', might encourage politicians to call for new Cutbacks. Cautious behaviour of AD directors also leads to Hierarchical Behaviour towards their AD staff. These employees become (even) more cautious than is common in a bureaucracy. Hierarchical Power of individual SGs, whose opinion often differs from the concern perspective, makes it hardly possible for the AD directors to be fully clear to their staff (Unclearness). This, again, makes them Cautious and slows down the change progress and initiatives.

In paragraph 5.1 we will discuss the characteristics of the civil service (bureaucracy, image, ministerial autonomy versus centralisation) and the prevailing dominant forces (demands from the Parliament and the Dutch Court of Audit, cutbacks by the Cabinet). In paragraph 5.2 we will relate the concern labels to the ministerial labels by describing the effect of the 'concern thought' on the transition. We will also describe the tension the AD-director experiences, given the fact that he

\footnotetext{
${ }^{2}$ Bureaucratism is used as term for (only) the negative characteristics of Bureaucracy: slow decisionmaking, extreme cautiousness, red tape, lust for rules and regulations, formalism and inefficiency.
} 
is a link between 'the concern', his SG, and his auditors (who are demanding professionals).

We will describe the effect of the project management on the transition and the chosen project management style related to communication theories in paragraph 5.3. In paragraph 5.4 we take both change agents together to be able to describe the observed change characteristics based on the dominant grounded theory codes. Here we relate managements' actions to change strategies and a behavioural management theory.

\subsection{The effect of circumstances on the AD-transition}

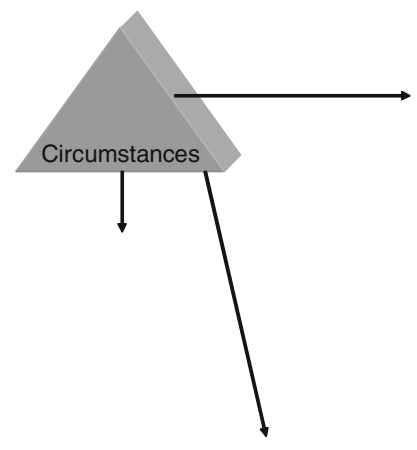

The triangle Circumstances is characterised with the codes 'Imposed change', 'Cutbacks' and 'Bureaucratism'. These three labels highlight the relationship between the civil service and the general public, the press and the parliament. They also influence the behaviour of government departments. In recent years, there has been an increase in the dissatisfaction with the civil service. The last five Cabinets reacted with cutbacks and studies on the image and culture of the civil service. In the Netherlands the tendency of politicians and advisors is to enforce the civil service to act like private interest organisations. But the government is not a company. The Parliaments criticism on a Minister focuses on the work of civil servants. Some Ministers hide behind their servants and parliamentarians often shine and become prominent at the cost of civil servants.

We now will discuss the characteristics of the civil service (bureaucracy, culture and image, ministerial autonomy versus centralisation) and the prevailing dominant forces (demands from the Parliament and the Dutch Court of Audit, cutbacks by the cabinet) in order to describe the effect of the circumstances on the AD-transition.

\subsubsection{The image of the civil services}

The government sector has been the object of fierce criticism since 1980. The belief in shaping the society from above has disappeared. This gave way to deregulation and a reduced role for government. At the same time, however, the role that the government should play in any particular policy area was not absolutely fixed. In certain areas, such as social security, the government did indeed take a step back, whereas in others, such as the environment and the fight against crime, it began to take a more active interest (Postma 1996). However, the dissatisfaction with the functioning and the performance of the government has increased especially in recent years: in 200065 percent of the population had the opinion that the Dutch government functioned well, but in 2002 this percentage decreased to 35 percent (Van Kemenade 2004). 
The citizenry wants a government that runs efficiently. 'Decisiveness without bureaucracy' is an often heard exclamation, both by the people and by politicians. But 'Bureaucracy' in this context has to be interpreted as 'Bureaucratism', the degeneration of bureaucracy that can also be found in other organisations besides the civil service: slowness, lust for rules and regulations, formalism, narrowmindedness, detailism. The government in this vision is reduced to a 'supermarket of public services' that needs to serve the citizens, who act as customers, in the fastest and best way. Thus the relationship between government and citizen is reduced to a strictly rational-business-wise relation (Van Kemenade 2004).

This cabinet did not decide on a drastic structural reorganisation: 'Good administration-good communication between government and citizens, giving the citizen more choices, eradicating the drive for regulations and bureaucracy and mobilising social organisations in finding the answer-might offer better solutions'. If we add to that the centralisation of quality management of government activities, this implicates 'a radical change of the administrative culture' (Van Kemenade 2004). The emphasis on policy preparation must move to execution; from plans, memos and regulations to result oriented and concrete execution.

In 2004 an action programme was launched with the object of modernising the Dutch Government. This Action Programme was called 'Andere Overheid' ('new government'). Its aim was building a powerful and decisive government, which puts the community in the centre. It entails improvement and taking initiatives on the following themes: improved services, less bureaucracy and a decisive organisation. In all sorts of tasks, a different way of working is necessary, such as teamwork, cooperation and listening to citizens. 'Andere Overheid' is more than a policy matter. It is a movement by and for government organisations and professionals in order to make government work more purposeful and society orientated. The role of the 'Andere Overheid' team was to boost the process. This was done by signalling problems and offering platforms for communication, by communicating confidence and good examples amongst all participants, and by signalling the processes that need improvement as well as by supporting change agents and joining forces (Andere 2006).

But the action programme also consisted of an integral reconsideration of the central governmental tasks. So 'new' could also mean 'smaller'.

\subsubsection{Cutbacks as reaction to the governments' image}

Politicians constantly promise better government performance with fewer civil servants. Recent Cabinets believed that the growing Bureaucratism could be stopped by cutbacks on the budgets:

- Balkenende ${ }^{3}$ I: 'determination without bureaucracy'. Target: a reduction of 11 percent.

- Balkenende II (and III): 'People need to realise that when we have opted for fewer regulations, we also need fewer civil servants'. Target: minus 16 percent.

\footnotetext{
${ }_{3}^{3}$ Balkenende refers to the Dutch Prime Minister and leader of the Christian Democratic Party (CDA).
} 
In the agreement of the three political parties that formed the cabinet 'Balkenende II' titled: 'Participate, more jobs, fewer regulations', one speaks about 'a government that does not come to the mark'. 'Excessive illness, bureaucracy, many and detailed governmental regulations, too much attention for policy creation and too little for execution, a complicated jungle of subsidies, and lack of maintenance: they are all signals of a less effective and less efficient than intended government. Moreover, without extra budget the performance can improve'.

'Balkenende I' describes the ideal of the sharp government as a government 'that characterises itself by less bureaucracy and regulations, concrete policy objectives, a decisive approach of lingering problems and recovery of responsibility in the society. The governments' effectiveness, power and 'ability to listen' must be increased'.

In a manifesto dated July 2006, the employers' organisations reacted to the crisis of the cabinet 'Balkenende II' with an idea to reduce the number of Ministries. A drastic reorganisation of the government must reduce the bureaucracy, the number of civil servants and Ministries. Their reasoning is: Fewer rules, less costs for the government.

During the weeks before the elections in November 2006, all political parties planned firm cutbacks for the civil service in order to reduce bureaucracy. The new Christian-red cabinet of Balkenende IV 'killed' the programme 'Andere overheid' and wants to find new ways of limiting the size of the civil service. They can use the plan the SGs wrote to reduce the civil service by 15,000 employees (NRC 2007).

The Council for the Civil Service (ROB) recognises that the road to the ideal sharp(er) and 'better listening' government is not an easy one to travel on. To increase the performance, it is not enough to change the structure and size of the government. Changes of structures that are not coupled with changes in the organisational culture will at the end have hardly any effect, as experience teaches us, in the private and in the public sector. The other way round: Attempts to change the organisational culture that are not accompanied by changes in the organisational structure, are empty rhetoric, or worse, distract the attention from the real problems (Van Kemenade 2004).

The Council of Economical Advisors (Koedijk 2007) wrote a report with recommendations for the Cabinet after researching the following problem definition: 'Why do reforms which try to make the government sharp and more efficient stick to intentions?' In spite of all rhetoric, the 'pressure of rules' does not decrease, and the excessive stress on new policy stays dominant to the disadvantage of the policy execution. The council listed five reasons for the lack of change in the status quo:

1. Simple information about finance and manpower are lacking. Responsibilities are badly organised and the boundaries between government and private sector are vague.

2. There are neither incentives nor mechanisms to prioritise actions, with as result no pressure for renewal and cost reduction.

3. The governmental management copies the private sector and fails to appreciate the unique qualities of the public sector. 
4. The Parliament does not have enough opportunities to investigate and lacks the means to give pressure against the cabinet's administrative machinery.

5. The importance of the design and timing of the reform policy is underestimated.

Koedijk (2006) argues in the newspaper NRC, that the public policy is little effective and hardly transparent when it is complex. Thinkers as well as doers cannot resist the temptation to govern a complex society with complex means. The complexity is amplified by management techniques that are meant for managing civil servants, but are based on distrust and the drive to control. The demand for transparency is answered with huge reports which try to provide justification. Their authors must have thought: If you can not convince them, confuse them. Koedijk mentions a group of top civil servants that wrote in the same newspaper (NRC 2004): 'A civil service has been created where people follow procedures instead of doing what is relevant and right. All the attention is focused on new policy, far too little on the execution of existing policy'.

\subsubsection{Bureaucracy and the fight against Bureaucratism}

An important feature of the Dutch public administration is that it tries to 'normalize' itself as much as possible. 'Normalisation' in this context is the mirroring of the public and private sector, creating as little differences as possible (Hondeghem and Vandenabeele 2005). In its advice on the effectiveness of the public service, the Council of Economic Advisors of the parliament (REA), which consists of five independent economists, strongly disapproved the inclination to consider the government as a company. 'The government is copying the business world, which underrates the unique qualities of the public sector' (Koedijk 2007). The Governmental sense of responsibility, democratic and constitutional understanding of civil servants needs to be cherished and subject of their permanent education' (Van Kemenade 2004).

'The government is [...] not a company. The government does not 'earn' income (it is 'expenditure driven'), it is not aimed at profit, and it is usually monopolistic and not dependent on product sales for a living. Much governmental work is hard to measure. The government distinguishes itself by 'its unique characteristic and the publicity of the politics and the-political-administrative decision-making, the specific aspects of representativeness, maintenance of authority and justice, and the fact that there are always unsatisfied customers with the political distribution of values'. The government derives its function and significance from the support of legitimated or legal authority. It is dependent on laws and regulations and functions in a constitutional frame. This frame demands from the government, to guarantee legal security, equality of rights and legitimacy, to operate democratically, and to be verifiable - and so-transparent and honourable.

This means that the civil servant cannot be a 'real' entrepreneur. As an advisor/ executor he can be creative and full of initiatives, but he must work within the political-administrative context of the democratic constitutional state'. [...] 'So critics or 'dissatisfied customers' of the government have to be critically looked at themselves. Could it be that the 'greyness' of civil servants points at the need for 
careful, rightful and fair action, instead of acting as they pleased? Do the civilians know that civil servants have to act according to rules and procedures and are examined sharply? Might their 'servility' be, positively interpreted as loyalty?' (Van Kemenade 2004).

The reasoning behind the choice for bureaucracy as organisation form of the government is primarily of a political nature and is based on the constitutional law. The primary reason for hierarchy, centralisation and formalisation within the public bureaucracy is the demand for clear and verifiable political responsibility. The Dutch governmental organisation is not a 'limited company'. Public management is not just about increasing the effectiveness and efficiency. Above all, it is about the legitimacy and legality of the other patrons of value than just the strictly economical values (Kickert 1995).

Bureaucracy is the appearance of management that especially massive organisations use to control a large number of people and to deploy them rationally to accomplish certain tasks.

Characteristics of Bureaucracy are:

1. the principle of fixed competences, arranged by rules;

2. the principle of the official hierarchy;

3. office is practiced from behind the desk on the basis of documents;

4. a specialized education is normally required;

5. the office implies a full day's work;

6. the practice takes place according to general and usually established rules (Lammers et al. 2000).

Bureaucracy implies that persons in authority have the right of obedience by virtue of the competences that are involved with the office. Weber calls the bureaucratic appearance of management more efficient and sharper; it also better guarantees continuity than the traditional balance of power, where one was slavish to office holder as a person (Lammers et al. 2000). This contrasts the idea of 'bureaucratism' that is characterised with terms like: red tape, inefficiency, and officiousness. Besides, bureaucracy tends towards maintaining itself, even when the original goal no longer exists. It becomes a goal in itself and is consequently conservative (Michels 1925 in: Lammers et al. 2000).

Still, Weber's empirical study of ancient bureaucracies (of China and Egypt among others) is of value for today's bureaucracies. His ideal type 'Bureaucracy' must be seen as a way of acting in the most pure form, not as a normative framework. Important critical control factors of the civil service can easily be related to Weber's characteristics of bureaucracy (Table 1).

The democratic Dutch constitutional state is based on the principle of the constitutional division of the legislative, executive and judiciary power: Montesquieu's classical 'trias politica'.

The constitutional state became mature in the nineteenth century and it proclaimed that:

- there must be a constitution with obligatory regulations for the relations between government and citizens; 
Table 1 Characteristics of Weber's Bureaucracy

\begin{tabular}{ll}
\hline Control factor & Based on the characteristic of Weber's Bureaucracy \\
\hline Legitimacy & $\begin{array}{r}\text { Specification of jobs with detailed rights, obligations, responsibilities, } \\
\text { scope of authority } \\
\text { Extensive use of written documents. The hierarchical relation is regulated, } \\
\text { including the justification }\end{array}$ \\
Transparency & $\begin{array}{l}\text { The office holder's work is separated from the private property } \\
\text { Integrity }\end{array}$ \\
$\begin{array}{l}\text { The office holders carry out their duties from a functional loyalty } \\
\text { They are appointed based on their skills and experience (e.g. not politically } \\
\text { elected). Purely functional points of consideration and qualities will } \\
\text { determine their selection and career }\end{array}$ \\
The office holder is formally appointed and earns a fixed salary \\
corresponding with the function and seniority
\end{tabular}

- where a separation of power is ensured especially:

- legislation in accordance with the parliament;

- an independent judiciary power, that decides in disputes between civilians as well as between citizens and the government;

- an administrative action based on the law and through which the civil fundamental rights and rights of freedom are defined and guaranteed.

Within the state design, the House of Representatives is allocated a firm role. Nowadays, it is criticised as swallowed by the bureaucracy. A 'fourth power', the administrative machinery, has the power of decision at their disposal, and this is tightly interwoven with the executive power. In 1969, Crince Le Roy introduced the term 'fourth power'. He stated that this is demonstrated by several scientific researchers. It is described as stronger than the other three 'powers' and harder to check. Reussing (Intermediair 2006) states, based on his theoretical and empirical research on the relation between politician and civil servants, that the bureaucracy acts fairly on its own authority and is hardly checked by administrators that "come and go'. Van Schendelen (Intermediair 2006) nuances this thought by mentioning the power of several interest groups that watch over civil servants and might take extraordinary actions, even when the parliament is at recess.

A motivating problem for the civil servant is mentioned by a secretary general as a reaction to the growing political 'hunger' to economise on the civil service. SG Bekker calls the cutback proposals in the political party programmes 'a un-inspiring message for the civil service. It seems that one is saying: we do not want the work you do' (FD 2006).

The same signal was given by the Parliament in 2004 (and again in 2005) when the party leaders decided to go on campaign instead of debating the yearly justification of the cabinets policy execution. The civil servants interpreted this as disinterest in the policy execution and in their work. The chairman of the House blamed these party leaders for contempt of parliament. The press calls it contempt of the citizens, when the 'truants' implicated that with their actions; they dissociate themselves on the usual 'rummaging in The Hague'. 
In the many contacts with auditors, I often noted this complaint of disinterest in combination with the idea that Parliamentarians do not understand the governance system nor the role of auditors within that system.

The members of Parliament generate a lot of work for these same civil servants with their ever-growing number of questions for the minister. Critics state that many of them are merely to bring the parliamentarians or their party into the spotlight. The way of judging a parliamentarian, e.g. by the number of formal questions for the minister, might be the reason for this increase. The Council of Economic Advisors (REA) of the parliament could acknowledge the increase $(50 \%$ within 4 years), but not the reasoning used by the critics.

\subsubsection{The imposed change versus ministerial autonomy}

In order for one to understand the impact of the tension between autonomy and the 'concern-thought' on the transition, one needs to understand how the Dutch Civil Service has evolved.

It is the constitutional system of 1848 , which still provides the context for the Dutch public administration of today (Van der Meer and Dijkstra 2000). The constitutional system made civil servants accountable to their minister instead of the King. It also made the minister responsible for his ministry. This ministerial responsibility led to a departmental 'compartmentalisation', which is still a prevailing characteristic of the Dutch Central Administration (Van der Meer and Dijkstra 2000). Compartmentalisation refers to an internal orientation of the different ministries. It often leads to resistance to cooperation on interdepartmental (or 'concern') issues.

However, it was mostly the process of 'industrialization, its social aftermath, and the development of a modern party system' that actually gave direction to the Dutch civil service (Van der Meer and Dijkstra 2000, p. 151). This process started in the end of the nineteenth century and it increased the size of the Civil Service (Van der Meer and Dijkstra 2000; Hondeghem and Vandenabeele 2005). The increased complexity of the public administration exposed the lack of intra- and interdepartmental coordination. Proposals and initiatives were formulated to tackle this problem. They, however, had little impact (Van der Meer and Dijkstra 2000; Hondeghem and Vandenabeele 2005).

Since 1919, a directive issued by the Cabinet has required that every proposal with financial consequences should first be assessed by the Minister of Finance. A study by Toikens in 1988 showed that although the cutbacks were often accepted in general, individual ministries tried to escape budget cutbacks for their own ministries. It was not until 1993 that the coordinating responsibilities of the Minister of Finance were laid down in the Government Accounts Act (Postma 1996).

'Concern-thought' is a term used by Dutch civil servants. In literature we did not find this term. It refers to the principle of interdepartmental cooperation and it is used in contrast to the ministerial autonomy. A system with collective cabinet responsibility for general government policy, but with ministers who exert their autonomy for their own policy areas, restrains the possibilities of ministers 
implementing their coordinating tasks (Van der Meer and Dijkstra 2000). The tension between, on the one hand, the need to cooperate, and, on the other hand, the focus on ministerial autonomy therefore has an impact on transitions within the public service. This is due to the fact that most transitions exceed the secluded compartments of the different ministries. An example is personnel management in the civil service. Many attempts were made to operate in a centralised interdepartmental manner and come together on this issue. Most of them failed. With the exception of top civil servants, the human resource policies remain with the individual ministers. This illustrates the level of fragmentation of the political system (Van der Meer and Dijkstra 2000).

\subsubsection{Analysis}

Dissatisfaction with the government drives politicians to cutbacks and reducing the civil service. No distinction is made between bureaucracy and Bureaucratism. At the same time citizens demand more from the government. Politicians pressure the minister to accomplish goals that cannot be fulfilled within a short notice. This again disappoints the citizens. Instruments that fit within private companies are introduced in the Dutch civil service as the solution for Bureaucratism. 'Of course' the transparency demand and the high legitimacy percentage stay untouched. The cabinet asks the civil servants to become effective, powerful and 'able to listen', but the circumstances make them even more cautious. The never ending critics and the absence of real interest in their work make them more sceptical.

The Cabinet wants entrepreneurial leaders with courage and willingness to stick their neck out (de Graaf 2005). However, these leaders act in a hierarchical bureaucracy where different agendas and contrasted sub-organisational goals exist. In a situation with recurring cutbacks, one first defends one's own decisions and finds inefficiency possibly elsewhere. As soon as transparency leads to attacks on the budget, the aim is to survive. Learning and entrepreneurialism need safety and trust (Senge 1990; Argyris 1992).

Within these circumstances, the financial oriented ADs were told to broaden their scope. Although they had to fight for their existence during the last decade (cutbacks and criticism), the audit directors were ordered from 'above' to experiment, change their formation and make their SGs believe in their new product (imposed change). They used the cutbacks as an argument for not appointing new young auditors with a non-financial background. The image of 'greyness' stayed. Outsourcing the audit function might have been an alternative but nobody had the political guts for that and there was no budget.

The communication within and between the ministries was formally structured. Discussions in interdepartmental meetings like IODAD were centrally coordinated. This made some parties within these meetings feel uneasy. When new ideas were not fully in line with the individual ministerial actions or policy, the proposed actions were vetoed or delayed by starting a new study group (Bureaucratism).

The Netherlands Court of Audit (ARK) is another force that strengthens tendencies to centralisation. The Court of Audit is independent of the government. Its 
tasks, power and legal status are vested in the Constitution and the Government Accounts Act, the act that governs the management of public finance. The ARK uses the outcomes of the (financial) audits of the internal audit departments and reviews the audit approach and dossiers. 'The Court of Audit investigates whether the funds received by all ministries, such as taxes, contributions and fees, are collected in accordance with the rules and are spent to achieve the targets set in the budget' (ARK 2005). With their stringent norm of $99 \%$ legitimacy and their rather straightforward reporting, the ARK encourages financial auditors to spend a large part of their time on financial audits. On the other hand, the ARK emphasizes the importance of a broad audit product and ADs role in the developing internal control of the ministries. One can conclude that the ARK supports the Quality Plan in words, but is keen on preserving the rather conservative financial audit practice of the ADs.

The Cabinet wants to change the governments' culture by creating room for the civil servant and by being clear about the organisation, the goals and the social responsibility. However, characteristics of transitions in general are: lack of clearness, lack of vision, too little support for learning, insufficient power and insufficient anchoring in the culture (Mastenbroek 2005, 2006). Trying to change the characteristics that are stimulated during a transition makes it hard to be optimistic about the results. The AD-transition shows the same unclearness, lack of trust, caution and political behaviour. Our research shows that these all increase conservatism. The belief in transparency during a transition presupposes that the auditors are able to handle the uncertainties that are made transparent. Trust in their AD-director and his capacities and power, become determinative for the civil servants' peace of mind.

\subsection{The effect of the 'concern thought' on the transition}

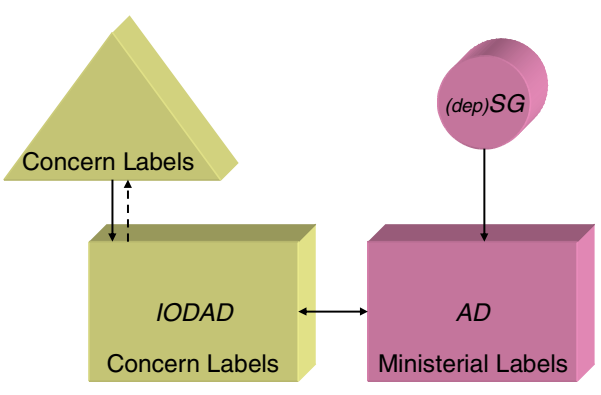

The triangle Concern labels (Politics, Unclearness and Mistrust) together with the hierarchical power of the SGs have a dominant influence on the changing $\mathrm{ADs}$ and on IODAD, in form of the Interdepartmental Meeting of their directors. The reaction of most directors is described as Cautious, Conservative and Survival oriented. Most AD directors act rather Hierarchical towards their auditors and stay Unclear about the transition. The auditors react Cautious and most of them are rather Conservative. We now will discuss an effect of the 'concern thought' as described in 5.1 and will also elaborate on its effect on the AD-transition.

\subsubsection{The Interdepartmental Policy Investigations (IBO)}

Within the Dutch civil service Interdepartmental Policy Investigations (IBOs) are used to find solutions to recognised problems, leading to a committee report and a Cabinets point of view based on this report. The investigation is done by (deputy) 
SGs, DGs and directors of different ministries, and it is completed with external experts. The forming of the committee is based on reaching a compromise; all parties that will be affected by the outcome have a say in it (polder model). Normally the report is written by the secretary of the committee working within one of the kernel departments (FIN or BZK).

The transition of the ADs and the related 'Quality Plan' are based on the IBOreport written by 'the Kordes committee'. The secretary of the project management was a FIN/CAD-employee. He was also the secretary of the IBO and author of 'the Quality Plan'. The CAD-director is the chairman of the interdepartmental meeting of audit directors (IODAD). He also was a present member of the IBO and member of the steering committee of the AD-transition. Although most Ministries were represented in the committee or in a meeting, one can conclude that just a few people took part in all the relevant committees and meetings, and they are key figures when it comes to this transition. These key figures of course have their own thoughts and interests. Within IODAD the interest was primarily the survival of the chartered accountants including their certification function. The autonomy of the chartered accountant and the professionalism of the governmental accountant play an important role in the AD-transition.

\subsubsection{Autonomy related to Professionalism}

According to Van Poucke and van Wijk (1995), the essence of Professionalism is the need for a reasonable amount of Autonomy. This need is determined by the specific character of the content of the professionals work and by the professionals' references. Both elements influence the degree to which the professional can be directed by his superior (Weggeman 1992; Vermaak 1997).

According to the professional, only he can judge the needs of his client and only he knows how to help his client. This is why the professional demands autonomy in the organisation and the possibility to steer his work process (Van Poucke and van Wijk 1995).

But the professional group (Royal NIvRA) also 'rules' its members. Royal NIvRA judges their work and sets the professional quality standards for them.

Managing the professional is not an easy job. This is obvious especially in changing organisations. The dilemma between changing demands on the organisation as a whole and wishes and demands from the professional is classical. The formulation of strategic intentions and steering on the realisation of them is easily seen as interference with the professionals' work. Professionals show stubbornness towards change (Weggeman 1992; Van Poucke and van Wijk 1995; Vermaak 1997).

\subsubsection{Analysis}

The Financial auditor, educated as a chartered accountant, has learned that it is important to report to an Audit committee, independent of top management. Objectivity is easily mixed up with independence. Organisational independence, 
e.g. by positioning the $\mathrm{AD}$ as high in the organisation as possible, is used as a means to guarantee objectivity. Never the less, chartered accountants easily see the community as their clients. Their loyalty is at first with them and their professional group. But of course, they are paid by their SG and work in an institution that is loyal to their minister. From the perspective of the chartered accountant, they need their autonomy, based on rulings from their occupational group, to stand for objectivity with or against their SG, in order to serve their minister.

Within 'the concern' several interdepartmental meetings of AD directors take place. These meetings can be seen as coalitions between the auditing professionals from the majority of the twelve ministries. They share the same tradition, have the same survival drive, but have to answer to different SGs. They claim their autonomy when the centralisation drive asks them to neglect ministerial policies or give in on the choices which their SG made earlier. On the other hand, the interdepartmental meeting can help them to make a fist against changes that threaten their occupational group standards.

The Ministerial labels, consisting of the AD with a rather dominant AD director, are characterised by an obvious interaction with IODAD. Within IODAD, the appointment of new non-RA-directors by the SG resulted in a split between the RA and the non-RA directors, when it came to how to handle the pressure related to the transition. The majority of the RA-directors put most of the energy in finding arguments in the rulings of their occupational group to preserve the financial certification role of the AD. In terms of the 'Quality Plan', one can characterise this attitude as Conservative, based on Professionalism and Survival.

IODAD had only a little influence on the concern labels (Politics, Unclearness and Distrust). An IODAD-representative attends cross meetings, which are carefully constructed to realise the overall accepted, but vague conclusions. In line with the characteristics of a bureaucracy, it often gives room for a private ministerial interpretation as the Dutch ministerial autonomy demands. The outcome often leads to a repetition of discussions within just a few years. Even some concrete decisions that are sanctioned by the cabinet are in fact overruled or discarded by an individual SG (Bureaucratism).

\subsection{The effect of the Project management on the transition}

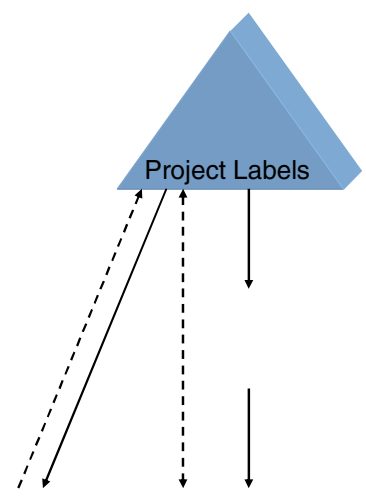

The triangle Project labels is characterised by the labels Caution, Stimulating and Informing. These labels emerged while coding the actions of the project management. In this paragraph we will describe some characteristics of the project management and the importance of communication. We use some theories on project and programme management and a communication theory to analyse the effect of the project management on the transition. We will end this paragraph with an analysis. 


\subsubsection{Project management}

During the past decades, the use of project management has increasingly been adopted as a way for organisations to achieve their objectives (Meredith and Mantel 2000). Project management enables an organisation to effectively use its resources through its ability to plan, implement and control the organisation's activities. In addition, project management is also a powerful tool in effectively using an organisation's human resources (Meredith and Mantel 2000). Nowadays, project management is particularly used as an approach to implement changes (Pellegrinelli 1997).

According to Meredith and Mantel (2000, p. 12) 'the basic purpose for initiating a project is to accomplish specific goals'. These authors point out that even though the main reason for organising a task as a project is 'to focus the responsibility and authority for the attainment of the goals on an individual or a small group', the project manager (PM) often lacks the necessary authority consistent with his responsibility. However, the PM is still expected to coordinate and integrate all activities required to reach the project's objectives.

Project management has advantages and disadvantages. In general the main advantage is that project management gives an organisation more control and efficiency gains. Other advantages mentioned are a sharper orientation toward results, better interdepartmental coordination and higher work morale (Meredith and Mantel 2000).

However, project management also has its negative effects. It can lead to a greater organisational complexity. One of the side-effects can be conflict. This stems from the fact that projects compete with functional departments for resources and personnel. There is also the earlier mentioned lack of authority of the PM (Meredith and Mantel 2000).

In their study on the definition of project management, Artto and Wikström (2005) note, that when project management started to develop, the focus was more on the efficiency rather than the effectiveness paradigm. According to Thiry (2004) project management is often based on a performance paradigm 'embedded in an uncertainty-reduction process'. This scholar calls for the need to adopt a different paradigm for projects and programmes. Artto and Wikström (2005) look at the movement in recent management literature where projects are brought to a more strategic context. These scholars point out that dependent or independent multiple projects can contribute to the fulfilment of organisations' strategic objectives.

According to Pellegrinelli (1997) the term 'programme' has been widely used to describe 'the organising structure and processes used to coordinate and direct projects'. However, 'programme management is not the same as multi-project management' (Pellegrinelli 1997). According to Thiry (2004) programme management needs to reflect 'the rhetoric and concepts of strategic long-term management, rather than the tactical short-term view of project management in order to gain executive management support and truly be able to support strategic decision management'. A comparison between a programme and a project is given in Table 2. 


\subsubsection{Communication}

In a change situation, communication is crucial. It is the one instrument to preserve trust, to get informed about the feelings of the participants and to be able to know when to respond. Argyris (1992) teaches us in his model II: To make the information concrete and applicable. A judgment or reproach must be specified in terms of behaviour. Ask for the opinion behind the reasoning and invite interlocutors to do the same. Mastenbroek (2005) writes about communication in his evaluation of the National Research on Change: 'It is not about newsletters [ ] but about the question of reaching everyone in a way that they know explicitly and specifically what the change will mean for them and for their work'.

Olsthoorn (1997) distinguishes forms of communication within organisations in Table 3 .

In a change process, all three communication forms are important. The diagonal communication best fits in Argyris' model II (1992) because it does not coincide with the balance of power within an organisation. Diagonal communication promotes cooperation between hierarchical levels.

\subsubsection{Analysis}

The project management actions are described in chapter 2 'The case'. The characteristics of these actions are 'informing' and 'stimulating' towards the AD directors and their (deputy) SG. Some of these actions created a positive climate for the change and some pilots showed the possibilities of the new AD. IODAD as a whole and the individual SGs received information about the 12 ADs. It was presented as a best practice summary. The project management talked with the SGs about a modern AD based on some research on the audit function in the Netherland, Europe and Canada. It reached individual auditors by means of a periodical and by organising seminars in cooperation with IODAD.

There is some direct influence of the project management on the AD staff, but just as much as the $\mathrm{AD}$ director permits. The project management was 'Cautious' not to violate the autonomy of the ministerial ADs. The periodical attempted to stimulate discussions, but it had little success. Most individual auditors are cautious and loyal

Table 2 Comparison of programmes and projects (Pellegrinelli 1997, p. 142)

\begin{tabular}{|c|c|}
\hline Programme & Project \\
\hline An organising framework & A process for delivering a specific outcome \\
\hline May have an indefinite time horizon & Will have a fixed duration \\
\hline Evolves in line with business needs & Has set objectives \\
\hline $\begin{array}{l}\text { May involve the management of multiple, related } \\
\text { deliveries }\end{array}$ & Involves the management of a single delivery \\
\hline $\begin{array}{l}\text { Focused on meeting strategic or extra-project } \\
\text { objectives }\end{array}$ & Focused on delivery of an asset or change \\
\hline $\begin{array}{l}\text { Programme manager facilitates the interaction of } \\
\text { numerous managers }\end{array}$ & $\begin{array}{l}\text { Project manager has single point responsibility for } \\
\text { project's success }\end{array}$ \\
\hline
\end{tabular}


Table 3 Three form of communication (Olsthoorn 1997)

\begin{tabular}{lll}
\hline Formal-direct & Formal-indirect (parallel) & Informal \\
\hline $\begin{array}{l}\text { Oral } \\
\begin{array}{l}\text { Vertical: top-down and/or } \\
\text { bottom-up }\end{array}\end{array}$ & $\begin{array}{l}\text { Written (pr audio-visuals) } \\
\text { From a central department } \\
\text { top-down }\end{array}$ & $\begin{array}{l}\text { Unplanned } \\
\text { Diagonal, horizontal, vertical }\end{array}$ \\
\hline
\end{tabular}

to their superiors; their discussions take place mainly horizontally, with their direct colleagues within their own AD and in educational spheres at their university.

Project management. Looking at Table 2, one can argue that the project management of 'the Quality Plan' has characteristics of both a project and a programme. Although the outcome was described in 'the Quality Plan', the ideas as well as the circumstances evolved. The outcome became 'multiple' and 'strategic'. The 'programme' manager facilitated the interaction of numerous managers. The term 'programme' better emphasizes the situation of twelve ADs that have to change within the context of their ministry; twelve ADs with their own transition supported by a centrally operating manager who tried to make the SGs and ADdirectors enthusiastic for the new broader oriented AD. This 'massaging' style is in accordance with modern organisational change theories (Schein 1999). Several interviewees however, characterised the program manager in his final year as 'pushy'. Project management 'needed to show some results'. Talking with the ADdirectors about changing their ADs is talking about changing themselves (Stoker 2005). Above all, people do not like to change. Convincing with arguments will hardly be effective; but showing people the positive effects of change in some pilot situation might well be effective (Mastenbroek 2005).

The project team consisted of the manager and a secretary. Some CAD employees temporarily contributed to the project, but the CAD acted merely as a service to IODAD. When IODAD organised events related to the transition they realised some synergy with the project team.

An important characteristic is the lack of formal power (authority) of the project manager. The project manager, however, is not held very much responsible for the outcome of the project. The steering committee started with the idea to implement a governmental structure in which the project management had to account for its actions. In time, the meetings of the steering committee turned into dialog rather than steering based on the reports. In practice, the project manager became the vicechairman and gradually the meetings were replaced by bi-lateral communication between project manager and individual members of the steering committee.

The 'sharper orientation toward results' is recognisable in this research. The project management kept the transition on the agenda by means of its progress reports. It recognisably influenced some (p)SGs and AD directors. Due to the power of the ministerial autonomy, other ADs were hardly influences by the project management. It was easily seen as the instrument of the kernel ministries and their 'concern thinking'. 
Based on discussions with AD-staff, the project management and some $\mathrm{AD}$ directors, we noticed three opinions on the effect of the project management:

1. 'The project management helped the more conservative AD directors. We started early and did not need the project efforts or the use of their instruments'.

2. 'The project management confirmed our internally started transition. 'Nice' for our (deputy) SG to hear that we were on track. Sometimes the project management exaggerated or had no eye for our primary product, the financial audit'.

3. Students of the post initial master course Internal/Operational auditing are most of the time in favour of the transition. They either are involved in the roll out of the new product or have no idea what the intentions are about. They notice little effect of the project managements' actions and often think that their management team is to blame for that.

But the project certainly contributed to the possibilities of transformation in accordance with 'the Quality Plan'. It also stimulated key-figures including employees of the several ADs to reconsider their primary opinion of the-in fact imposed-transition. Nevertheless, the transition of many ADs was not complete when the project management ended.

Communication. The project management was aware of the importance of communication. They saw it as their contribution, in addition to facilitation. They, for example, financed two pilots to give the auditors an opportunity to experience the intended broad audit goals and to let this experience spread like a commercial campaign. The approach of the project management was showing what is possible, giving a platform for success, talking about opportunities and facilitating where initiatives are lacking. They believed in change supported by setting examples that created enthusiasm among top management.

The project management used all three forms of communication mentioned above, but was careful in its discussions with staff-members of the ADs. It did not want to obstruct the AD-directors in their managing of the AD. Most of the time, the formal-direct communication was limited to the top hierarchical levels (SG, DG, AD-director). The written communication consisted of the progress reports and a periodical. The reports were discussed in IODAD and read by management and directors. They were not distributed among the AD-staff members. The ADdirectors informed their staff as they pleased.

The periodical ZIEN* instead, is a form of formal-indirect communication. It was send to the staff members and anyone else interested. It consisted of personal experiences and opinions of individual auditors and elicited some discussion between the auditors. The project management organised a road show, but not all the AD-directors invited the project management to address their staff. IODAD and the project management organised several seminars where discussions could be held on the transition but often the participants did not perceive the meetings as a platform for open discussion. Although a change of attitude of the seminar participants in 2003 versus 2005 was clearly noticeable, in our view the mood was still more resigned than enthusiastic. 
Informal communication is hard to accomplish in a hierarchical culture. The sharing of new audit experiences was easily formalised in an audit 'blood type' meeting. These meetings were held within the office hours and IODAD appointed a chairman and expected a plan and a justification for the hours spend. Informal bottom-up initiatives failed because subordinates thought that their superiors might not appreciate the sharing of personal perceptions of the experiences on new audits. The communication between the AD-directors was a form of horizontal communication. Based on interviews, we characterise the communication as coloured and optimistic. Just like the round table meetings between $\mathrm{AD}$-directors in private companies, the colleagues easily accepted the somewhat rosy misrepresentation of the reality as a positive contribution to the occupational group and to the transition. Besides, one does not turn away from a professional colleague.

An organised course for senior AD-management, called ZIN-course, was powerful in its essence because it gave the AD-management the opportunity to speak-out about possible frustrations, discuss their worries and share their successes. However, most reactions we heard makes us conclude that a large number of the participants were not convinced of the desirability of the transition, were critical of the performance of their director and found themselves unfit to motivate their (assistant) auditors. The AD-directors had hardly any role in the ZIN-courses. And, like predicted in theories of managing professionals (Weggeman 1992; Vermaak 1997), the participants were reluctant to discuss other than on content level. During the transition, we missed the open dialog to bring up the real causes of the resistance to this transition. Argyris' Model II demands explicating the judgements and reproaches in terms of behaviour. Management must be open in expressing its opinion and needs to activate others to express their thoughts on his opinion (Argyris 1992).

We already mentioned the difference between plans and promises and the perceived change. Argyris recognises a distinction between 'espoused theory' and 'theory-in-use'. He assumes that in general, managers are more engaged with policy and procedures than with humans. People react with emotions, they are unpredictable and critical. Managers try to avoid this confrontation (Argyris 1992). Honesty, openness and dialog are often mentioned as the key to success but do not fit in the organisational culture at hand. Defence mechanisms take over, but they are never talked about. Argyris teaches us that they grow and flourish subterraneous. He speaks of the leadership dilemma: 'competent incompetence' when the defence mechanisms come to the surface.

AD-management was capable of living with the suppressed defences but showed to be incapable of dealing with and discussing them. The hierarchical organisational structure of most ADs with experienced chartered accountants in the management team suggested, especially to the newly attracted operational auditors, that the transition had not the highest priority of the AD-management. In spite of all kinds of structured top-down information, not all the auditors knew the status of the transition process. At the end of 2005, some AD-employees on different levels said that they still worked the way they used to do before 'the Quality Plan'. In addition, that they knew that their management appreciated this. They were not in particular interested in the new policy because it was not relevant for their daily work. A 
structure change like the dismantling of sectors in favour of an audit pool was no guarantee of real AD-broad cooperation. It proves that communicating a new vision, only affects the people that are really altered by it.

\subsection{The observed change characteristics}

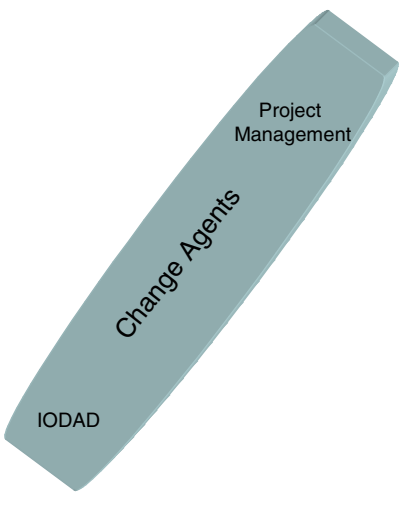

would direct him.

In this paragraph we first describe the relation between IODAD and the project management. We than elaborate on the change characteristics by a description of the grounded theory codes, followed by a theory of change and a behavioural management theory that helps us to describe the characteristics of the change agents' actions.

\subsubsection{The relation between IODAD and the project management}

The project manager that IODAD recruited is a former Director General of the Ministry of Health, Welfare and Sports. The project structure changed into a structure with a steering committee that consisted of different stakeholders from several ministries. In time, the meetings of the steering committee turned into dialog rather than steering based on the reporting. In fact, the project manager became the vice-chairman and gradually the meetings were replaced by bi-lateral communication between the project manager and individual members of the steering committee. The relationship with IODAD became informative.

The project management did not really get a grip on IODAD, and visa versa. The IODAD-members contributed to the project as long as it did not interfere with the ministerial autonomy.

This situation was somewhat peculiar because of the fact that the IODADmembers had, in practice, the main responsibility for the implementation of 'the Quality Plan' within their AD. In the existing structure, the project management informed the IODAD-members about the status of the transition of their ADs and about the plans to help them to transform in line with 'the Quality Plan'. IODAD could have been an excellent platform to share knowledge and experience based on 
pilots and actions regarding the transition. When it came to organising seminars and informing their employees with a periodical, it worked in cooperation with the project management. Nevertheless, our research outcome characterises IODAD as a rather defensive committee. Although at several points divided, IODAD clenched their fists against developments the majority of the AD-directors feared or found important to influence. They engaged in discussions with the professional organisation of accountants (Royal NIvRA) about independence, with the Netherlands Court of Audit about depth and detail of audits and with their controlling colleagues about their role and independence. On these subjects, IODAD was roughly divided in the Registered Accountants (RA) and the non-RAs.

In time, the goals of project management and IODAD diverged. If the ADs had acted in accordance with 'the Quality Plan', the project manager's goals would have been achieved. However, the AD-directors had found their ideal position between the different preferences of their stakeholders. This was specifically between the preferences of their Secretary General and the professional group Royal NIvRA. Other stakeholders, including internal management and FEZ, the IODADcolleagues, project management and the somewhat divided AD-staff, had their own ideas about the transition and had different priorities. The AD-directors communicated in terms like: 'We already have changed; we have broadened the audit scope and we will proceed in changing towards integrated audit'. They use new undefined terms. Then they pointed to the changed circumstances, like the cutbacks and the new possibly conflicting IBO.

\subsubsection{Related grounded theory labels}

Our research shows a number of characteristics that we represent as labels. These labels overlap and influence each other. The use of a qualitative data as a tool analyses made the interrelation between these labels visible. Figure 4 shows the relation between the labels that are most frequently scored on important text fragments. Figure 4 is followed by an analysis.

The labels in Fig. 4 can briefly be described as follows:

- Power: Authority to chose and make others follow your ideas and instructions. Power is used in a process to obtain interpersonal influence and can be categorized in position power, leader power and personal power.

- Politics: Acting in the most sensible or prudent way in the circumstances, with regard to the own (business) interests to gain an advantage or achieve a goal.

- Lack of clarity (Unclearness): AD-management is not clear about their vision or their choices. AD-management does not 'walk the talk' or keeps stressing priorities other than in line with the transition.

- Caution: Taking great care to avoid possible danger. Here danger is related to survival and conservatism.

- Conservatism: General unwillingness to accept change and new ideas.

- Distrust: (or Mistrust): firm belief in the honesty, goodness, worth, justice, power, etc. 


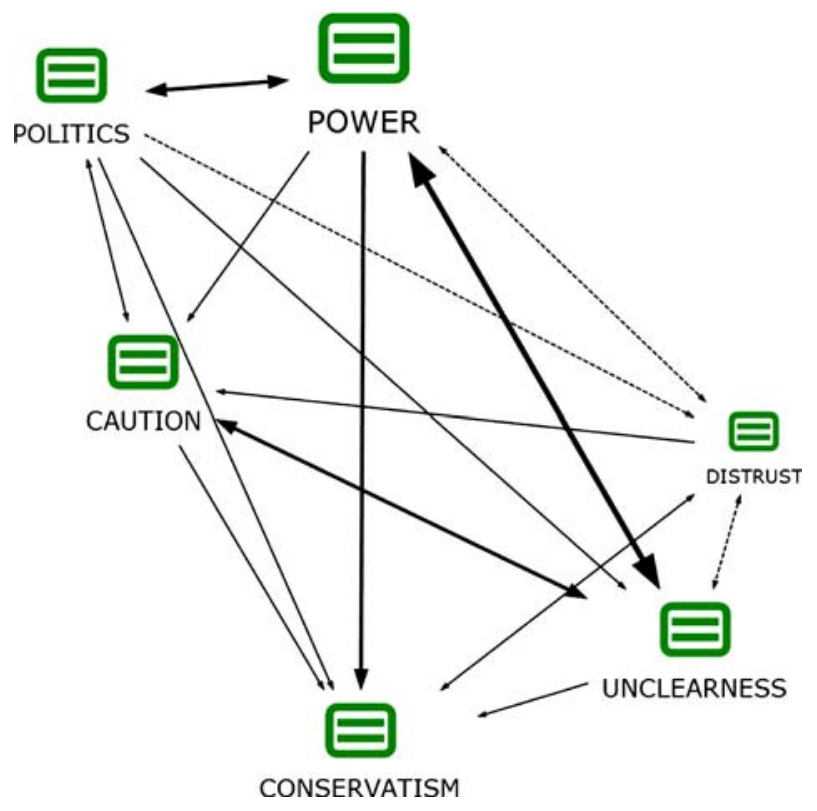

Fig. 4 Related labels

The most important relation is between Power and Unclearness; obviously it is accepted when top officials are unclear about their vision, give contradictory orders or change their opinions in short term. This unclearness is accepted when people are reminded of the Political environment, the demand for transparency and the severe criticism. We often heard that civil servants do not act just because they think that their superior will not appreciate it. Loyalty to the minister in fact means loyalty to your superior because he again must be loyal to his superior. Unclearness combined with this loyalty make the civil servant Cautious.

This Caution combined with Power and Politics increases Conservatism. Mistrust is the less obvious label that interacts with most of the other labels and works as a lever.

\subsubsection{Change strategies}

'Rapid developments in the organization's environment, market demands, and internal processes are common reasons for companies to start more or less drastic change processes (Boonstra 2003). In addition, the need for efficiency and reduction of transaction costs also call for organisational change, particularly a switch from vertically integrated companies to other types of organisations (Beer and Nohria 2000). However, many change initiatives fail to reach their goal. According to Beer and Nohria (Beer and Nohria 2000), in organizational theory, two dominant theories, or archetypes, can be distinguished, namely: the theory $\mathrm{E}$ and theory $\mathrm{O}$. 'Theory $\mathrm{E}$ is change based on economic value: shareholder value is the only 
legitimate measure of success, and change often involves heavy use of economic incentives, layoffs, downsizing, and restructuring. Theory $\mathrm{O}$ is change based on organizational capability: the goal is to build and strengthen corporate culture'. In practice, most companies either use one theory or the other or actually end up randomly mixing in bits of each. Zammuto (2001) argues that the latter leads to 'the maximization of costs and the minimization of the potential benefits of each theory'. Beer and Nohria (2000) also note that even though the approaches to change embedded in both theories are valid, one needs to take the tension between both theories into account.

Boonstra (2005) also argues that not one single theory of change is perfect or even desirable. According to this author there is not such a thing as a perfect way of organising. Based on research conducted by the University of Amsterdam (UvA), this author distinguishes five types of change strategies. Their research shows that they reflect different change capabilities (Table 4).

Analyses. The more a strategy is positioned to the left hand site, the more it can be typified as a theory-E. The more we move to the right, the more the strategies resemble theory-O. Generally speaking the change strategies of IODAD can be positioned at the left side of the model. According to Boonstra (2003) this results in a small to very low capacity to change. The project management can be positioned at the right-hand side of the model. Although it sees itself as 'discovering', its actions reflect a 'pulling' attitude. Using indirect power the project aimed at participation and contribution of employees. They certainly fought for dialog and even conflict and tried to change the attitude of the ADs from outcome oriented to problem or even future oriented. Circumstances and limitation of budget and time finally made the ADs output oriented.

Table 4 Change strategies and change ability (Boonstra 2003)

\begin{tabular}{|c|c|c|c|c|}
\hline Power strategy $13 \%$ & $\begin{array}{l}\text { Planned change } \\
\text { strategy } 23 \%\end{array}$ & $\begin{array}{l}\text { Negotiating } \\
\text { strategy } 18 \%\end{array}$ & $\begin{array}{l}\text { Programmatic } \\
\text { strategy } 25 \%\end{array}$ & $\begin{array}{l}\text { Interactive } \\
\text { strategy } 21 \%\end{array}$ \\
\hline Pushing & Moving & Negotiating & Pulling & Discovering \\
\hline $\begin{array}{l}\text { Steering by top } \\
\text { management }\end{array}$ & $\begin{array}{l}\text { Initiatives by top } \\
\text { management }\end{array}$ & More parties & Participative & Interactive \\
\hline Legitimate power & Output oriented & $\begin{array}{l}\text { Outcome } \\
\text { oriented }\end{array}$ & $\begin{array}{l}\text { Problem } \\
\text { oriented }\end{array}$ & $\begin{array}{l}\text { Future- } \\
\text { oriented }\end{array}$ \\
\hline $\begin{array}{l}\text { Contribution } \\
\text { controller }\end{array}$ & Expert power & $\begin{array}{l}\text { Position } \\
\text { power }\end{array}$ & Indirect power & $\begin{array}{l}\text { Imaginative } \\
\text { power }\end{array}$ \\
\hline Power-pressure & $\begin{array}{l}\text { Contribution } \\
\text { advisors }\end{array}$ & $\begin{array}{l}\text { Contribution } \\
\text { parties }\end{array}$ & $\begin{array}{l}\text { Contribution } \\
\text { employees }\end{array}$ & Associating \\
\hline \multirow[t]{2}{*}{ No participation } & Rational-empirical & Negotiation & $\begin{array}{l}\text { Normative-re- } \\
\text { educative }\end{array}$ & $\begin{array}{l}\text { Dialog and } \\
\text { conflict }\end{array}$ \\
\hline & $\begin{array}{l}\text { Limited } \\
\text { participation }\end{array}$ & $\begin{array}{l}\text { Political } \\
\text { process }\end{array}$ & $\begin{array}{l}\text { Lot of } \\
\text { participation }\end{array}$ & $\begin{array}{l}\text { Lot of } \\
\text { interaction }\end{array}$ \\
\hline $\begin{array}{l}\text { Very low ability to } \\
\text { change }\end{array}$ & Low ability to change & $\begin{array}{l}\text { Small ability to } \\
\text { change }\end{array}$ & $\begin{array}{l}\text { Limited ability to } \\
\text { change }\end{array}$ & $\begin{array}{l}\text { High ability to } \\
\text { change }\end{array}$ \\
\hline
\end{tabular}


Fig. 5 Triade factors (Pioesz 1999)

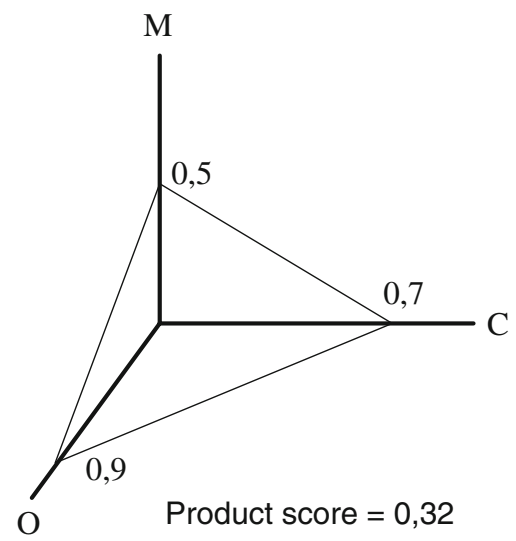

\subsubsection{Change abilities}

According to Pioesz (1999) behaviour stems from the combination of Motivation, Capacity and Opportunity. Motivation refers to the degree that a person is motivated to reach a certain goal or has interest in showing a specific behaviour. Capacity is about a person's competences or capability to show a specific behaviour. Capacity could therefore be seen as more of an individual's internal characteristic. The external circumstances that might either reinforce or stop a person from showing a specific behaviour is referred to as Opportunity.

The multiplication of the 'Triade-factors': Motivation, Capacity and Opportunity reflects an expectation of the effectiveness of behavioural change. Often, according to Poiesz, the factor which is stimulated has the least leverage. Most of the time Motivation scores less than Capacity and Opportunity, but instead of working on Motivation, actions are based on the growth of what already scores relatively high. This is recognised by many participants in organisational change (Fig. 5).

Analyses. As mentioned earlier, the project management had no formal power. Aiming at motivation, the project had to pass the AD directors (Autonomy) or motivate these directors to experiment. Here Mistrust, Unclearness and Politics stand in their way. Therefore, the project management financed pilot operational audit projects in order to provide deputy SGs with more conservative ADs and with an opportunity to see new audit products. Spending part of the project managements' budget on pilots within these more conservative surroundings, effected the type of demand for audits (opportunity) and on the audit capacity (skill) via coaching made by external experts.

The motivation-aspect is made visible by the structured IODAD-actions: seminars and periodicals. Both are strongly top-down and project management was not always satisfied with them. The motivation to learn and experiment, and to discuss within voluntarily originated groups, was killed by IODAD using 'economic' arguments. IODAD asked for proof of the 'progress' of these activities. In 2004, these differences in preferred attitude and project managements' habit to report progress as its gains, chilled the relation between both change agents. 


\section{Conclusions}

At the start of the transition project as well as at the end of 2004, there was an important difference between the 12 ADs in product scope and definition, working method and organisational structure. These differences can partly be explained by the characteristics of the ministries. However, the personal views of the SG, directors and AD-management and their relationship were the main causes of the differences.

For most of the ADs, we conclude that the transition only changed the daily process for some of the employees. Within some ADs, the audit work mainly changed in appearance. For instance, some earlier audit work labelled as 'financial' is now labelled as 'operational audit'. Some ADs have changed progressively in terms of customer-directedness (one of the recommendations in the letter of the cabinet, 2001). They are taking part in the risk management process. Although this was not foreseen in 'the Quality Plan' it helped to bring SGs and ADs closer together. This sometimes resulted in new audit objectives.

Change of the AD-director sped up the transition process, especially when the new director originated from outside the dominant governmental accountancy group. Although The Kordes Commission already emphasized the importance of an excellent manager as AD-director, the appointment of four non-RA directors caused some commotion within IODAD.

There is no doubt that the actions of the change agents effected the transition that started with 'the Kordes Committee' and 'the Quality Plan'. Project management reflected the conservative attitude of some AD-directors. We are not aware of serious research by the project management or IODAD on the causes of this attitude. In addition, neither IODAD nor project management had formal authority to force the audit directors to implement their publicly expressed intentions.

The political influences made top management 'unclear' in the eyes of the ADstaff. Lack of a clear view enhances conservatism and the attempt to survive. There is a lack of trust between the Ministries that is intensified by the standardisationtendencies from the government (the concern-thought) and the political environment (with a drive to reduce the civil service). All this at right angles to the Cabinet's ambition regarding the civil service: openness, transparency, mobility and organisational learning. The intended broader scope of the ADs gives the ADdirectors the possibility of being more critical of the responsibilities of their colleagues (policy directors, FEZ, DGs) than the old scope: the certification of the annual reports. This is only acceptable when the AD-director really changes his image from 'rigid' to 'accommodating' and 'indulgent'. Instead of being outsourced, the AD potentially gained power. Still the majority of the AD-directors are cautious and conservative. They know that they can easily overplay their hands.

Within the ADs, professionalism and a conservative audit planning hamper a quick development of operational auditing. Lack of trust in the broad audit scope as a permanent product, and a conservative definition of financial audit as the ADproduct, make the transition hard.

Looking at the project management, we conclude that they had no choice but to embrace a 'massaging' style (O-stream change). This is because of the lack of 
formal power in combination with the somewhat weird situation that the ADdirectors are at the same time change agents and object of change. Boonstra (2005) supports this hypothesis in general, when he stresses that only the Interactive change strategy gives a high ability to change. In that strategy interaction, dialogue and conflict, associating and future-orientedness are important. One needs to be able to 'discover'. Although these characteristics fit with the 'talk' about the government as a learning organisation, the reality still is that the civil service is characterised by Bureaucratism. In this article we described the 'walk' of SGs, AD directors and AD staff. With the described 'Circumstances' there is little hope that in short term all key persons will be able to 'walk the talk'.

What we can learn from this transition is that it is important to thoroughly investigate the causes of the status quo, before choices regarding organisational change are made. The characteristics of an organisation are there because key persons balanced their personal preferences, organisational opportunities and restricting circumstances.

A preferred change style needs to be supported by all change agents. But the project management lacks the formal power to make the AD directors change. The latter are both change agent and object of change. This unusual situation needs to be changed before arguments can affect a real dialog.

Within the civil service change is hard to realise. The differences between what politicians tell the public about what they think is important for the civil service and what they actually demand from the civil servant (including budget and consistency of policies) is huge. The demand for $100 \%$ openness in policy realisation, $99 \%$ legitimacy of their expenditure, combined with an event driven demand for explanations of choices and actions and a drive to 'hang the minister' when possible seriously conflicts with the cabinets view on the modern civil service:

Give space to employees, spread a clear vision, take responsibility and adopt a vulnerable attitude. Being transparent on the governments' achievements stimulates and needs to be well communicated (de Graaf 2005).

In our future research we will describe the change of the Dutch ADs in de period 2007-2008 and we will test the outcome of our grounded theory research. We will focus on those factors that make transition processes in governmental bureaucracies more predictable. We expect to give future project leaders some more chance to reach their projects goals.

Open Access This article is distributed under the terms of the Creative Commons Attribution Noncommercial License which permits any noncommercial use, distribution, and reproduction in any medium, provided the original author(s) and source are credited.

\section{Literature cited}

Andere. (2006). Modernising government in the Netherlands. http://www.andereoverheid.nl/ AndereOverheid/web/metamenu/international.htm.

Argyris, C. (1992). On organizational learning. Oxford: Blackwell Business.

ARK. (2004). Working towards VBTB-compliant budgets: Progress in 2002-2003. http://www. rekenkamer.nl/9282200/v/indexdom.htm. 
ARK. (2005). Homepage of the Netherlands Court of Audit. http://www.rekenkamer.n1/9082400/v/.

Artto, K. A., \& Wikström, K. (2005). What is project business? International Journal of Project Management, 23, 343-353.

Beer, M., \& Nohria, N. (Eds.). (2000). Breaking the code of change. Boston, MA: Harvard Business School Press.

Boonstra, J. (2003). Dynamics of organisational change and learning: An introduction. Amsterdam: SIOO.

Boonstra, J. (2005). Weloverwogen kiezen van veranderstrategieën; Iedereen ziet veranderen vanuit ander perspectief. Management and Consulting, pp. 21-23. [NL].

de Graaf, Th. C. (2005). Brief van de minister voor Bestuurlijke Vernieuwing en Koninkrijksrelaties, de heer mr. Th.C. de Graaf, aan de voorzitter van de Tweede Kamer der Staten-Generaal, die het kabinetsstandpunt verwoordt over het advies van de Raad voor het Openbaar Bestuur 'Cultuur met een FORS postuur'. [NL].

Dick, B. (2002). Grounded theory: A thumbnail sketch. http://www.scu.edu.au/schools/gcm/ ar/arp/grounded.html (on line).

FD. (2006). Harde kritiek topambtenaar op politici. Het Financieele Dagblad, 20 oktober 2006. [NL].

Glaser, B. G. (1978). Theoretical sensitivity, advances in the methodology of grounded theory. New York: Sociology Press.

Glaser, B. G. (1992). Basics of grounded theory analysis: emergence vs. forcing. New York: Sociology Press.

Glaser, B. G. (1998). Doing grounded theory: Issues and discussions. New York: Sociology Press.

Glaser, B. G. (2001). The grounded theory perspective: Conceptualization contracted with description. New York: Sociology Press.

Glaser, B. G. (2003). The grounded theory perspective II: Description's remodelling of grounded theory methodology. New York: Sociology Press.

Glaser, B. G., \& Strauss, A. L. (1967). The discovery of grounded theory, strategies for qualitative research. New York: Sociology Press.

Haig, B. D. (1996). Grounded theory as scientific method. Philosophy of Education Society.

Hondeghem, A., \& Vandenabeele, W. (2005). Values and motivation in public administration: Public motivation in an international comparative perspective. In Joint EGPA-ASPA Conference: Ethics and Integrity of Governance-First Trans-atlantic Dialogue Leuven (Belgium), 2-5 June, 2005.

Intermediair. (2006). De vierde macht aan de macht. Intermediair, June 15, 2006. [NL].

Kickert, W. J. M. (1995). (red.). Veranderingen in Management en Organisatie bij de Rijksoverheid. Dordrecht: Kluwer. [NL].

Koedijk, C. G. (2006). Regeer begrijpelijk en stop de controledrift. NRC Handelsblad, November 15, 2006. [NL].

Koedijk, C. G. (2007). Lof der eenvoud. Advies nummer 2007/1 van de Raad van Economisch Adviseurs (REA) Januari 24, 2007. [NL].

Kordes, F. (2001). De auditfunctie in het VBTB-tijdperk, uitkomsten van het Interdepartementaal Beleidsonderzoek (IBO) Competitieve Dienstverlening (CDV) Accountancy, aangeboden aan de Tweede Kamer der Staten-Generaal bij brief van de minister van Financiën van 20 augustus 2001. Kamerstukken II 2000/2001, 27891 Nr. 1. [NL].

Lammers, C. J., Mijs, A. A., \& van Noort, W. J. (2000). Organisaties vergelijkenderwijs; Ontwikkeling en relvenatie van het sociologisch denken over organisaties. Utrecht: Aula, Het Spectrum. [NL].

Locke, K. D. (2001). Grounded theory in management research. Thousand Oaks: SAGE Publications.

Mastenbroek. (2005). Het eerste Nationaal Onderzoek Verandermanagement. Amsterdam: Intermaat B.V. [NL].

Mastenbroek. (2006). Het tweede Nationaal Onderzoek Verandermanagement. Amsterdam: Intermaat B.V. [NL]. http://www.ManagementSite.nl.

Meredith, J., \& Mantel, S. (2000). Project management: A managerial approach. New York: Wiley.

Miles, M. B., \& Huberman, A. M. (1994). Qualitative data analysis: A sourcebook of new methods (2nd ed.). Newbury Park, CA: Sage.

NRC. (2004). Controledrift bedreigt 'public spirit' van de overheid. NRC Handelsblad, December, 7 2004. [NL].

NRC. (2007). Topambtenaar gaat overheid hervormen. NRC Handelsblad, Februari, 21 2007. [NL].

Olsthoorn, A. J. C. M. (1997). Cultuur en communicatie. Een verkenning naar de samenhang tussen bedrijfscultuur en communicatiebeleid. Houten/Diegem: Bohn Stafleu van Loghum. [NL]. 
Pellegrinelli, S. (1997). Programme management: Organising project-based change. International Journal of Project Management, 15(3), 141-149.

Pennekamp, P. B. H., \& Vlasveld, P. J. J. (2004). Project Kwaliteitsplan auditfunctie Rijksdienst; Eindrapportage, Conclusies een aanbevelingen voor de komende jaren. Internal report. [NL].

Pennekamp, P. B. H., \& Vlasveld, P. J. J. (2005). De auditfunctie van de rijksoverheid: hoe nu verder? Audit Magazine, No. 2, juni 2005. [NL].

Pioesz, Th. B. C. (1999). Gedragsmanagement, Waarom mensen zich niet) gedragen. Wormer: Inmerc B.V. [NL].

Postma, J. K. T. (1996). Control and management of government expenditure: Institutional structure of budget decision-making. In C. Kool, et al. (Eds.), Essays on money, banking, and regulation (pp. 57-68). Dordrecht: Kluwer Academic Publishers.

Schein, E. H. (1999). Proces advisering: Over de ondersteunende rol van de adviseur en het opbouwen van samenwerking tussen adviseur en client. Amsterdam: Nieuwezijds. [NL].

Senge, P. M. (1990). The fifth discipline, the art \& practice of the learning organization. New York: Doubleday/Currencey.

Stoker, J. I. (2005). Leiderschap verandert. Rede Bijzonder hoogleraar leiderschap en organisatieverandering. Rijksuniversiteit Groningen. Assen: Koninklijke Van Gorcum. [NL].

Thiry, M. (2004). 'For DAD': A programme management life-cycle process. International Journal of Project Management, 22, 245-252.

Van der Meer, F. M., \& Dijkstra, G. S. (2000). The development and current features of the Dutch Civil service. In H. A. G. M. Bekke \& F. M. Van der Meer (Eds.), Civil systems in western Europe (pp. 148-187). Cheltenham: Elgar.

Van Kemenade, J. A. Van (2004). Cultuur met een FORS bestuur. Naar een andere Rijksdienst. Raad voor het Openbaar Bestuur (ROB). [NL].

Van Poucke, A. B. M., \& van Wijk, H. E. (1995). Besturing van professionele organisaties; Van praktijk naar onderneming. Stichting Management Studies. Assen: Van Gorcum. [NL].

Vermaak, H. (1997). Men zegt dat professionals niet te managen zijn, Nyenrode. Management Review, 7 , 12-27. [NL].

Weggeman, M. C. D. P. (1992). Leidinggeven aan professionals: het verzilveren van creativiteit. Deventer: Kluwer Bedrijfswetenschappen. [NL].

Werken. (2005). Werken bij het rijk als je verder denkt. [NL]. www.WerkenBijHetRijk.nl.

Zammuto, R. F. (2001). Review: Breaking the code of change by Michael Beer \& Nitin Nohria. Administrative Science Quarterly, 46(4), 796-798.

\section{Literature used}

BiZa. (2000). Arbeidsmarktmonitor Rijksdienst 2000: De Accountancy bij de Rijksoverheid, Directie Personeelsmanagement Rijksdienst van het Ministerie van Binnenlandse zaken en Koninkrijksrelaties. [NL].

Buelens, M. (2005). Veranderen - een koud kunstje. Focus Hooglerarenreeks Verandermanagement, 20, december 2005. [NL].

Cozijnsen, A. J., \& Vrakking, W. J. (2003). Handboek verandermanagement. Theorieën en strategieën voor organisatieverandering. Deventer: Kluwer. [NL].

Deal, T. E., \& Kennedy, A. A. (1982). Corporate cultures. The rites and rituals of corporate life. Reading, MA: Addison-Wesley.

de Caluwé, L. I. A., \& Vermaak, H. (1999). Leren veranderen, Een handboek voor de veranderkundige. Alphen aan den Rijn: Samsom. [NL].

de Geus, A. W. (1997). The living company: Habits for survival in a turbulent environment. Boston, MA: Harvard Business School Press.

de Jong, A. J. (1995). De gelaagde organisatie. Assen: Van Gorcum. [NL].

de Korte, R. W. A. (2005). Is de internal auditor een 'professional'? Controllers Journaal, No. 21, November 2005. [NL].

de Korte, R. W. A. (2006). The transition of the Dutch Ministerial Audit Departments: Change never starts because it never stops. Paper for the 4th European Academic Conference on 'Internal Audit and Corporate Governance', May 2006. 
Frissen, P. (1986). Literatuurbeschouwing, Organisatiecultuur: een overzicht van benaderingen. Management \& Organisatie 1986/6, pp. 532-544. [NL].

Goulding, Ch. (1998). Grounded theory, the missing methodology on the interpretivist agenda. Qualitative Market Research an International Journal, 1, 50-57.

Hage, M. (2007). A stakeholders concern: Towards an economic theorie on stakeholder governance. Van Gorcum: Erasmus University Rotterdam, Assen.

Handy, C. B. (1985). Understanding organizations. London: Penguin Books.

Hart, P. 't, e.a. (2002). Politiek-ambtelijke verhoudingen in beweging. Amsterdam: Boom. [NL].

Metselaar, E. E., \& Cozijnsen, A. J. (1997). Van weerstand naar veranderingsbereidheid: over willen, moeten en kunnen veranderen. Heemstede: Holland Business Publications. [NL].

Pellegrinelli, S. (2002). Shaping context: The role and challenge for programmes. International Journal of Project Management, 20, 229-233.

Pennekamp, P. B. H., \& Vlasveld, P. J. J. (2006). Reforming the auditfunction. Internal Auditor, April 2006, pp. 69-72.

Porter, M. E. (1985). Competitive advantage. New York: The Free Press.

Prud'homme van Reine, P. (2000). De cultuur van de accountant. De accountant, No. 11, Juli/August 2000. [NL].

Quinn, R. E. (1997). Diepgaande verandering. Schoonhoven: Academic Service. [NL].

Rosenthal, U. (1988). Bureaupolitiek en bureaupolitisme: om het behoud van een competitief overheidsbestel. Inaugurele rede Leiden. Alphen aan den Rijn: Samsom H.D. Tjeenk Willink. [NL].

Schein, E. H. (1985). Organizational culture and leadership. San Francisco, CA: Jossey Bass Publications.

Strauss, A. L., \& Corbin, J. (1990). Basics of qualitative research. Cambridge: Cambridge University Press.

Swieringa. (2006). Gedoe komt er toch. Focus Hoogleraren reeks Verandermanagement. February 2006. [NL].

Van Mierlo, J. G. A. (1995). Bureaucratie en bureaucratisering. Een theoretische en praktische verkenning van recente ontwikkelingen in de publieke sector en de particuliere sector. Hoofdstuk 4.5/D0500 voor Besturen en Innovatie: Handboek voor bestuurders en manager. Houten: Bohn, Stafleu en Van Loghum. [NL].

Weick, K., \& Quinn, R. (1999). Organizational change and development: Episodic and continuous changing. Annual Review of Psychology, 50, 361-386.

\section{Author Biographies}

Ronald de Korte is Programme Director of the postgraduate course Internal/Operational Auditing, Erasmus University Rotterdam. He is a lecturer of Auditing and IT Auditing at the Erasmus University, Business University Nyenrode and the University of Groningen. As a Ph.D. candidate he conducts research into government audit services and behavioural aspects of changes in Internal auditing.

Gert van der Pijl is professor of IT Auditing at the Erasmus University in Rotterdam, The Netherlands. $\mathrm{He}$ is responsible for the postgraduate programs in IT Auditing and Operational Auditing. He also is director of research of the Erasmus School of Accounting and Assurance. His research areas are among others: IT Auditing, Information Economics, Business IT Alignment, IT Security, IT and Management Control. 